\title{
Vulnerability, justice and care
}

OÑATI SOCIO-LEGAL SERIES, VOLUME 12 ISSUE 1 (2022), 211-230: VULNERABILIDAD Y CUIDADO: UNA APROXIMACIÓN DESDE LOS DERECHOS HUMANOS - VULNERABILIDADE E CUIDADO: UMA ABORDAGEM DE Direitos HuMANOS

DOI LINK: HTTPS://DOI.ORG/10.35295/OSLS.IISL/0000-0000-0000-1254

RECEIVED 12 JULY 2021, ACCEPTED 25 NOVEMBER 2021, VERSION OF RECORD PUBlisHed 01 FEBRUARY 2021

\section{ANNALISA VERZA* (D)}

\section{Abstract}

The concept of vulnerability is once again assuming a central role in ethicalpolitical-legal discourse. This is the case both in relation to its neo-liberal reinterpretations, aimed at placing the responsibilities and consequences of vulnerability onto the vulnerable subject itself, and, on the contrary, to the theses - the result, to a large extent, of a reworking of the ethics of care - of authors such as Martha Fineman, Judith Butler, Martha Nussbaum, Catriona Mackenzie and others, who use the idea of vulnerability as a basis for re-founding and reorganising liberal policies, freeing them from fictitious concepts such as the alleged basic autonomy of the human being. The article aims to analyse the different meanings and implications that, due to the accentuation of different aspects of vulnerability, add up to produce such a multifaceted concept, in order to try to clarify the conceptual implications and practical consequences that vulnerability may elicit.

\section{Key words}

Vulnerability; justice; care

\section{Resumen}

Una vez más, el concepto de vulnerabilidad está asumiendo un rol central en el discurso ético-político-jurídico. Es el caso tanto en sus reinterpretaciones neoliberales,

\footnotetext{
The article has been produced within the PRIN project Soggetti di diritto e vulnerabilità: modelli istituzionali e concetti giuridici in trasformazione. Vulnerability. An earlier version of this article appeared, in Italian, in $\mathrm{O}$. Giolo, B. Pastore (ed.), Vulnerabilità. Analisi multidisciplinare di un concetto. Carocci, Roma, 2018. This version is published with kind permission of the editors.

* Annalisa Verza is an associate professor of Sociology and Philosophy of Law at the University of Bologna. Her main research areas concern liberalism and multiculturalism, the impact of digital technology on our society's democratic processes, legal feminism, and the Arab origins of sociology of power and civilisation. Her most recent books: 2021, Ibn Khaldun and the Arab Origins of the Sociology of Power and Civilisation; 2020, Postfemminismo e neoliberalismo. A cura di Annalisa Verza e Silvia Vida. Email: annalisa.verza@unibo.it
} 
dirigidas a hacer recaer las responsabilidades y consecuencias de la vulnerabilidad sobre el propio sujeto vulnerable, y, por el contrario, en las tesis -resultado, en gran medida, de una reelaboración de la ética del cuidado- de autoras como Martha Fineman, Judith Butler, Martha Nussbaum, Catriona Mackenzie y otros, que usan la idea de vulnerabilidad como base para refundar y reorganizar políticas liberales, desembarazándolas de conceptos ficticios como la supuesta autonomía básica del ser humano. Este artículo se propone analizar los diferentes significados e implicaciones que, debido a la acentuación de diferentes aspectos de la vulnerabilidad, se suman para producir un concepto tan polifacético; y ello, para intentar aclarar las implicaciones conceptuales y consecuencias prácticas que la vulnerabilidad puede generar.

\section{Palabras clave}

Vulnerabilidad; justicia; cuidado 


\section{Table of contents}

1. Vulnerability and the paradox of its protection........................................................... 214

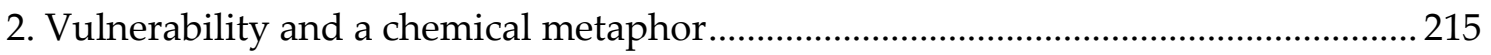

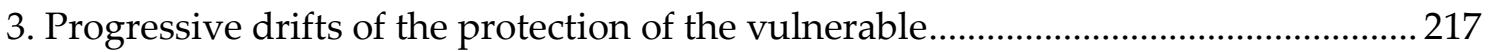

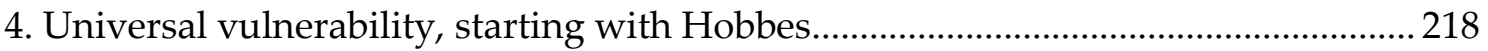

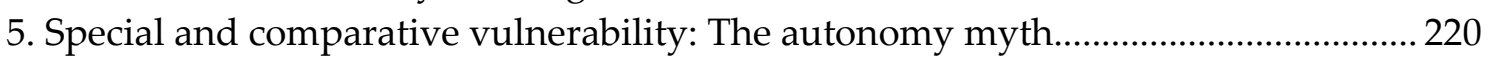

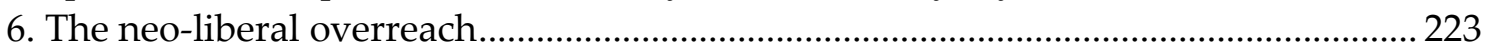

7. The current rethinking of vulnerability as the foundation of a justice system........... 224

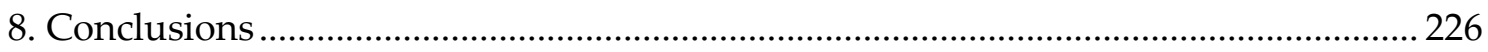

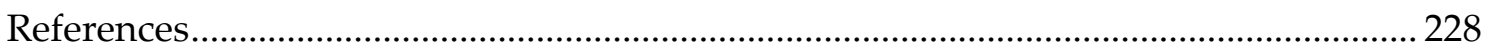




\section{Vulnerability and the paradox of its protection}

The vulnerability imparted to Achilles by his heel has passed into myth. However, this did not cause him to be remembered as "fragile": the vulnerable Achilles was, on the contrary, the strongest of the Achaeans. The "physical" concept of fragility indicates an essentially stable and static characteristic of any physical material; however, the vulnerability of complex entities - natural, human or social - is something else. In fact, while recalling the idea of a constant potential for injury (vulnus), this property is not necessarily expressed in a stable manner in a subject: its emergence depends decisively on its dialectical relationship with the environment with which it interacts.

The environment, in fact, can be the source of its "wounds" (vulnera), just as, on the other hand, the environment is also the factor that can help the wounds to heal, accommodating them and placing them in a framework of meaning that allows them to be metabolised. Vulnerability, therefore, has to be understood as a "liquid" element of identity, not ascriptive but dynamic, which can appear at different times, can be latent under the surface or can even be structured as a "long-term" vulnerability, called upon to explode at a deferred time.

Moreover, it incorporates an important paradox: in reality, in complex systems - such as social systems, or personality systems, or even Parsonsian "behavioural organisms" (bodily realities) - the very strategies deployed to reinforce and protect them can, if pushed beyond a certain point of equilibrium, result in a particularly exacerbated supervulnerability. In short, vulnerability can be triggered by the very effort to focus frontally on it in order to prevent and escape it, controlling or denying the continuous reactive confrontation with the environment.

This can be clearly seen at an organic level: in medicine, for example, the evident iatrogenic and pathogenic effects on the organism (initially condemned by the Austrian philosopher Ivan Illich) produced by the drugs used to heal it, have prompted important information campaigns against the abuse, or overly flippant use, of antibiotics. In the same way, in the field of personality, the extremely "fragilising" effect of excessive protection on subjects sheltered "under a bell jar" is something well known even to our distant ancestors.

But the same thing can also be observed in the development and involution dynamics of social and super-organic entities, such as civilisations themselves. Indeed, there is a great amount of literature describing the aetiology of the paradoxical weakening of the social body as an effect of comfort, wealth and protective, top-down social planning. ${ }^{1}$ Cato the Censor wrote: Diversisque duobus vitiis, avaritia et luxuria, civitatem laborare, quae pestes omnia magna imperia everterunt. ${ }^{2}$

Similarly, even the much more refined theories of some of the greatest historians, such as Ibn Khaldun (2005), Edward Gibbon (1996) and Arnold J. Toynbee (1988), have strongly emphasised the existence of an important and recurring causal connection that moves in this direction. In their theories, it is a progressive weakening of the largest and

\footnotetext{
${ }^{1}$ See Tainter $(1957,1988)$. But Durkheim also insisted on the fact that more complex societies marked by specialisation and functional integration are more exposed to the risk of internal disaggregating anomie.

2 "The city is afflicted by two opposing vices, avarice and luxury, ruinous maladies which have brought down all the great empires": quoted in Livy, Roman History, XXXIV, 4.
} 
most powerful political entities, and the advance of a progressive vulnerability, paradoxical and developed from within', that accompanies the strengthening and consolidation of power within them and the rationalisation of their organisational structure. At the very moment when the strongest societies reach a level of stability that abstractly shields them from possible future evils, they are inevitably struck by a sort of "disease of progress" that renders them, compared to other social groups (less complex, less rich, but more capable of self-assertion), devoid of defensive antibodies, and, therefore, more vulnerable.

Vulnerability, therefore, understood as the potential for injury, seems conceptually opposed to a situation of invulnerability. Yet, when the latter is pursued and produced through a protective securitarian isolation rather than by accepting the universality of its incumbency and by training for a contextualised ability to endure (or, even more virtuously, according to Martha Fineman, to acquire resilience to the injuries that come from the environment), the risk is that, once the securitising action has exceeded a certain limit, points of unforeseen and circular conjunction will appear between the two extremes of vulnerability and its opposite. In other words: if it is denied, and not accepted and integrated as an ineliminable element of life, vulnerability tends, in the end, to present its own bill for settlement.

As we shall see, this statement is of particular importance today. at a time when the concept of vulnerability is once again assuming a central role in ethical-political-legal discourse. This is the case in relation to its neo-liberal reinterpretations, aimed at placing the responsibilities and consequences of vulnerability onto the vulnerable subject itself. But this is the case also in relation, on the contrary, to the theses - the result, to a large extent, of a reworking of the ethics of care - of authors such as Martha Fineman, Judith Butler, Martha Nussbaum, Catriona Mackenzie and others, who use the idea of vulnerability as a basis for re-founding and reorganising liberal policies, freeing them from fictitious concepts such as the alleged basic autonomy of the human being.

\section{Vulnerability and a chemical metaphor}

In the domain of chemistry, in addition to stable compounds or elements, there are others that are tendentially unstable, very reactive, and destined, because of their structure, to attract transformations and reactions. In a somewhat analogous way, even in the world of literary symbols - from Greek tragedy to later myths - many great dramas start with figures embodying characters whose structure already evokes the conflicts and problems that will characterise their destinies. In an ideal bridge between these two dimensions, even in the macro-chemistry of the large living molecules that we, as human beings, are, and in our interactions, there are situations of imbalance that, due to their internal logic, seem to dynamically attract reactions in the environment and produce transformations. And vulnerability, ${ }^{4}$ as a potentiality that elicits reactions and produces transformations in the environment, seems to represent one of these

\footnotetext{
${ }^{3}$ As is well known, Toynbee, who elaborated on Ibn Khaldun's theses, argued that the extinction of great civilisations is due to a weakening developed from within: as he argued, "Civilisations die by suicide, not by murder".

${ }^{4}$ But the same thing is invoked by the parallel concept, although expressed in the negative, of security (Verza 2016, p. 241).
} 
"chemically reactive" concepts. In fact, the very concept of vulnerability immediately calls up the idea of some consequence, of some dynamic effect - in a defensive or aggressive sense - complementary to it, which should be released or generated by it.

It is because of this essential and ineliminable "live" dialectic that vulnerability establishes with what surrounds it and reacts with it that to dissect the concept on the cold table of analytical investigation and to sub-distinguish it, as Catriona Mackenzie does, in its different possible expressions, ${ }^{5}$ is not sufficient to capture it - however useful and enlightening this exercise might be.

It is only by considering it in its living and dynamic relations with social physics, in which vulnerability is an "active" and reacting characteristic, that one can inductively observe, on the basis of the "chemical" metaphor proposed earlier, the transformations and consequences that it produces or recalls.

Macroscopically, these consequences, which are more or less ethically oriented, can generally be divided into two groups. ${ }^{6}$

The first is provided by consequences of an oppressive type and is clearly linked to the instinct - unfortunately very strong, primary and anthropologically, perhaps Darwinistically, ineradicable in our species - to crush those who present themselves as weak. It is with regard to this that Isaiah Berlin spoke, realistically, of an inherently, and irretrievably "crooked" timber of humanity. ${ }^{7}$

Indeed, when morality, justice, or law, or other types of interest, do not intervene to curb these instincts, the unstable molecule of vulnerability often combines with aggression and in fact, as neo-liberal logic would have it, attracts aggression. According to this view, not only is aggression prompted by the presence of an aggressor, but also by the presence of a victim already intrinsically prepared for victimhood - the original pole of attraction for a potential aggressor, which is in turn required to enable vulnerability to realise its potential, to become its own project, a self-fulfilling prophecy.

That vulnerability attracts the predatory instinct, if not already protected by moral, political, social and legal structures, is a "Hobbesian" fact, empirically inducible from the simple observation of reality: Mother Nature herself, for evolutionary purposes related to the good of the species, turns out to be much more aggressive than protective with vulnerable subjects.

On the other hand, it is in the sphere of reasons for action which stand out against a background of ethical, political, and legal theorising on justice that vulnerability, in its various forms, attracts, by contrast, compensatory consequences and functions in such a way as to justify the protection of the vulnerable from aggression, on ethical, rational, or prudential grounds. In terms of justice, such compensatory and remedial action presents as ethically due, as a corrective and "artificial" reassessment of vulnerability's imbalances, whether it is a question of compensating for a universally shared

\footnotetext{
${ }^{5}$ Mackenzie (Mackenzie et al. 2014, especially pp. 7-13 and 33-59) distinguishes intrinsic (universal), situational (context-dependent), pathogenic (dependent on oppression, injustice or even the side effects of remedies to them), dispositional, or actual vulnerability.

${ }^{6}$ See Judith Butler $(2004,2009)$ and her theory of bodily vulnerability and the reactions it induces.

${ }^{7}$ Berlin's (1991) "crooked timber", however, surely has deep roots, shaped by evolutionary, anthropological and psychological factors.
} 
vulnerability, or of focusing on particular vulnerabilities. But it requires the background of a solid moral, legal and/or political apparatus, to support - and constantly refresh the motivation and convictions that justify this.

The stability of a policy of this kind is wholly dependent on the ability of this justificatory structure to strongly support, within the social group, these ideals of morality and justice. In fact, if such ideals were left to the ethical sense of individual subjects alone, and not supported by continuous political commitment, they would inevitably tend to yield (due to a form of ever-impending akrasia that easily weakens them) to the tendency not to compensate and even, in fact, to take Darwinian advantage of the vulnerability of others - if not materially, at least through the mere eudaimonistic "positional" advantage generated by the disadvantage of others. ${ }^{8}$

\section{Progressive drifts of the protection of the vulnerable}

To make the picture even more complex, some forms of protection actually seem to incorporate latent elements of aggressive oppression, and therefore, while being oriented towards the goal of protection, end up being very close to the model first presented here of a paradoxically vulnerabilising protection.

First of all, there are situations in which vulnerability is re-elaborated as a factor capable of stimulating, precisely because of its disarming nature, a positive attraction, i.e., a situation that does not require, precisely because of this attractive force, any particular deontological and impositive schemes upon which to feed. There are, for example, situations in which inequality of force, due to its impotent and static nature, does not generally stimulate aggression (think of the feelings aroused by children, puppies, even by young and docile wives lacking - in the traditional patriarchal context - any economic autonomy and protection). These provoke an attractive tension in the strong who are seeking - again, through a sort of "chemical" complementarity - the vulnerable". This situation of "happy" complementarity, however, when it does not obliquely become a Trojan horse for strategies capable of developing into a real "power of the weak" (widespread, and often conscious, even codified since the classic Art of War by Sun Tzu), often finds its counterpart in a situation of dependence on the other. This is a situation which may lead, in other ways and with different degrees of intensity, to the possibility of injury and disempowerment for the subject "at the mercy" of the other (Dodds 2014).

In the legal sphere the situation produced by this type of protection translates into the so-called "legislation of protection". This includes, for example, the rich corpus of norms created, over time, with the declared aim of protecting women - norms that often have paternalistically entailed, in reality, the substitution of other decision-making subjects for the autonomy and subjectivity of the individual vulnerable persons protected "for their own good", even "against their will".

\footnotetext{
${ }^{8}$ This point refers to the well-known eudaimonistic "positional" theories of James Duesenberry and Robert H. Frank, according to which our perception of well-being is defined in relation to our positioning with respect to other subjects in our reference group (cf. the American saying, "Keeping up with the Joneses").

${ }^{9}$ An important hexagram (number 9) of the Chinese book of wisdom, the Yi-Ching, states that "we often need someone smaller than ourselves". Also, the ideologies of courtly love and romantic love both developed by incorporating the exaltation of the protection of the vulnerable.
} 
It should first be said, therefore, that vulnerability attracts (even stable) situations of dependence, which do not configure, as in the Hobbesian model, open aggressions, but which produce situations where power operates most of the time to the disadvantage of the vulnerable subject, who is constantly even more disempowered as a result of being protected. This is so even if, in certain cases, the scenario can be reversed. Even ethics of care has not failed to reflect on the results that this kind of asymmetrical situation of care/dependence often engenders (Kittay 1999).

A second kind of paradoxical protection occurs when vulnerability, instead of being accepted and gradually integrated in a living dynamic, is fixed as an abstract and qualifying label upon the "vulnerable subject" to whom it applies. Understood in this way, because of this rigidity (even more stigmatising when it becomes engrained in the rationalised circuit of the bureaucracy of welfare "care"), the protection against vulnerability, by contributing to weakening the subjects and loosening their ability to react, may ultimately represent a handicap to life.

The fact that natural and complex systems weaken precisely when their vulnerability is artificially focused, defined, isolated from the system and overprotected shows, in fact, how the precautionary and standardised labelling of a subject as being in need of protection can easily end up producing paradoxical results. This can be seen in the physical or psychological overprotection of children, in the hospitalisation or excessive isolation of biological bodies from the bacterial micro-world and, finally, in subjects socially placed under protection, and subjected, for this very reason, to a defining "labelling" as "fragile persons" that paradoxically hinders their independence and emancipation from those very labels. As David Matza (1964) showed, for example, in the differently "deviant" sphere of the criminological study of delinquency, any operation of "signification" and labelling of the "different" risks triggering a reactive process capable of favouring, paradoxically, a consolidation of their marginality and deviance.

In general, therefore, it is not only the case that vulnerability, in nature, tends to "chemically" attract aggression (or the correlative structuring of a relationship of power and submission). If protection is not well calibrated so as to avoid paradoxical effects, vulnerability also (even when ethically framed, and artificially compensated for according to models ranging from the Hobbesian to the policies advocated today by the ethics of vulnerability) always runs the risk of slipping into a covalent bond that imprisons the one being protected in a relationship of dependence and a state of constant indebtedness. It may even, ultimately, produce a handicap in itself.

\section{Universal vulnerability, starting with Hobbes}

The cornerstone, the original element around which liberal theorising (and not only that) has been, from the beginning, organised and built (Fineman and Grear 2013, 22), is precisely the concern for vulnerability, ${ }^{10}$ or, more precisely, for the possibility of suffering evil. This is a condition shared by all: a vision of vulnerability, therefore, not only markedly universalistic, but also endowed with a motivational force capable of

${ }^{10}$ Other authors, such as Goodin $(1985)$, Kittay $(1997,1999)$ and Nussbaum $(2006)$, have instead criticised contractualism in its entirety, arguing that such an approach does not take vulnerability and dependence into account in any way. 
showing how, when faced with this danger, submission to political and normative even absolute - power is convenient for all, and, in fact, necessary.

"Segnius homines bona quam mala sentiunt", commented the oldest Romans, remarking on the fact that the memory of the fear of the advancing Carthaginian threat remained more vivid than the relief of the victory just obtained, even after the fighting had ended. This statement, reported in Livy's Annals (xxx,21) lends itself perfectly to describe the human asymmetry that underpins the very foundations of the social covenant: for man in general, sensitivity to evil, actual or feared (and, therefore, the fear linked to the awareness of human vulnerability and mortality), normally exceeds or surpasses, in terms of the importance attributed to it, sensitivity to good.

Following this line of thought, at the very beginning of the process that would later lead, through modern contractualism, to the path of liberalism and democracy, Thomas Hobbes also made the "negative" concern for universal human vulnerability and the importance attributed to protection from evils (preponderant over the "positive" maximisation of the "right to everything") the central concern capable of motivating anyone (even the strongest man, insofar as he too is, conditionally, vulnerable) to stipulation of the social contract as an ideal to be pursued.

In short, the awareness of human, universal vulnerability, and the correlative impulse to protect it, and not consideration of justice, good or truth, is the factor that, at the decisional and practical level, was considered by Hobbes as the key reason for each participant in the contract to resolve to delegate its power to the Leviathan - a power aimed at translating into legal rules the otherwise opaque games of relations and power, and, at least, to guarantee life. The priority accorded to survival - and, thus, to the need to ensure protection in relation to the most common and radical of the factors of fragility - can also be understood by considering what the greatest damage looming over the bleak background of Hobbes's picture in the state of nature might be, where aggression is the only "chemical" reaction foreseen for vulnerability: the loss of life itself. An irreparable damage, therefore, which totally overwhelms (like a Dworkinian trump) any other consideration, incommensurable compared to any other variation, however important, in one's hedonic state. ${ }^{11}$

It is not on the basis of morality or justice (considerations which will only make sense later) but on the basis of this basic universal vulnerability, which unites everyone in the name of common mortality and the fear of evil, that the social contract's rationality is originally assessed - and with it the law, finally justified (in a first liberal impulse) on the basis of the rational interest in self-protection of the individual subjects themselves. Similarly, the natural rights outlined in more detail in Locke's view of the social contract were also conceived as aimed, in this sense, at guaranteeing life and protecting against common vulnerability.

It is true that even in Hobbes's theory there are internal differentiations between subjects who are vulnerable to a greater or lesser degree; what is more important, however, is the fact that, in this theory, the logic that determines the contractual choice is not the

\footnotetext{
${ }^{11}$ On the rather relative hedonic capacity provided by the prospects of a positive improvement in one's status, the studies of Daniel Kahnemann and Amos Tversky (1979) on the so-called "treadmill effect" are fundamental.
} 
articulated thinking that considers the degree of vulnerability of each, but the simple, binary logic: $0-1$. Precisely because of the incommensurability of the ultimate evil to be avoided (death), all subjects (in this sense, on an equal level with each other) are seen as potentially vulnerable, and, therefore, as having a reason to renounce their natural aggressiveness in order to set prudential limits to the impending violence which could affect their lives.

It is, thus, the state's monopolisation of violence (which does not actually eliminate it, but circumscribes it and rationally controls it, limiting where it can arise and making norms of the possible means of protection against it) ${ }^{12}$ that constitutes the cornerstone of modernity.

This consideration accompanied, in a more or less rhizomatic manner, the entire development of Western legal-philosophical thought, eventually resurfacing in many of its most characteristic moments (see also Turner 2021). We find it again, for example, in H.L.A. Hart's The Concept of Law (1961), which takes up Hobbes's theme (seen in this perspective) and underlines, in relation to the truisms that establish a minimum content of natural law, how human vulnerability represents the reason for the legal limitation of violence in this world. But it also appears in John Rawls' Theory of Justice (1972), which, similarly, is primarily oriented towards the protection of human vulnerability in opting not for an "optimistic" (Natarajan et al. 2006, pp. 303-4) maximax principle but for a "pessimistic" maximin principle. The latter is aimed at maximising the minimum conditions of life, thus giving precedence, over the prospect of maximising the best possible conditions, to the prospect of securing the "lower" limits set by our vulnerability and due, also, to the randomness of the "genetic lottery".

\section{Special and comparative vulnerability: The autonomy myth}

In the theories briefly presented above, vulnerability acts as an ethical-political reagent because of its universality (and, therefore, because of the common potential for injury or damage it evokes, assumed to be the same - fundamentally and in an abstract way - for all human beings). On the other hand, vulnerability is also a concept that, in relation to its concrete and embodied expressions, is much more often enunciated, in both common and specialised discourses (for example, in medicine, psychology, physics, etc.), as a contextualised and intimately comparative concept.

In this second sense, vulnerability is essentially identified when it emerges above the median line, or above "normality", in the same way that concepts such as "high" or "strong" are judgements that we have reason to express only when we have to indicate something as "higher" or "stronger" than average. In short, from this point of view, vulnerability counts as such when it needs to be conceptualised and thematised for some reason, i.e., for being, in some sense, special and qualified.

If it is true, thus, that, in the first of the two meanings identified above, no subject can be said to be invulnerable, it is also true that, in the unfolding of different real-life situations, some subjects will show smaller or greater levels of vulnerability. ${ }^{13}$ Paraphrasing a

\footnotetext{
${ }^{12}$ A similar view of the rationale behind the basic norms of society can also be found in Roger Commons' institutionalist conception (1934) and in his definition of the so-called "going concerns".

${ }^{13}$ See Zanetti 2019 on the relation between perception and vulnerability.
} 
famous expression taken from George Orwell's Animal Farm - which highlights, moreover, a slippery slope linking the two meanings, universal and special - it is true that everyone is equally vulnerable, but some are more so than others.

The surpassing of the median point that matters in this sense, however, is the one that deviates from a precise model: the liberal model of the autonomous and independent individual, which - initially conceived as a tendential, normative model, an ideal goal to be achieved - has been sliding more and more, in the history of liberal thought, towards a different interpretation aimed at making it a descriptive standard. A pattern, indeed, for defining not a goal to be achieved, but a model of normality (assumed, therefore, to have already been achieved by most people).

Liberalism has been nourished in this by some contradictions, internal to its own ideals: while, on the one hand, it has been hinged from the outset on the centrality of the protection of universal vulnerability, on the other it has incorporated into its own functional assumptions an underlying patriarchal power structure which - to be consistent with its egalitarian values - it should have opposed. This structure was so deeply rooted in society that it was only called into question by feminist thought after the theoretical developments from the 1970s onwards.

At least until Betty Friedan's (1976) "unveiling" of the ideology underlying the "mystique of femininity", 14 the very pervasiveness of the patriarchal model made it difficult to focus on the role played by its power dynamics in establishing that model of normality against which the "most vulnerable" could be defined as such, thus shifting the philosophical-political discourse towards emphasising a distinctly "fringe" understanding of "vulnerability".

By placing the vulnerabilising manifestations of patriarchal culture within the free zone of the "private" domain, liberal culture has, thus, endorsed this ancient asymmetry, promoting, in fact, a status of privileged autonomy in some (adult males - to whom, moreover, from another point of view, vulnerability is forbidden) at the expense of the subjugation and vulnerability of others (women, legally and socially deprived of autonomy and therefore socially driven to vulnerability). In this decisive way it has therefore contributed to conceiving and giving plausibility to the idea of the "autonomous (male) subject" which, together with the correlated presupposition of rationality already seen in Hobbes, strongly permeates all Western liberal thought (Pateman 1988; see, recently, Deneen 2018).

The Enlightenment project itself gave an important impetus to this vision. In fact, by placing at the centre of its vision the "autonomous and independent" man, his rights, his independence, his rationalised supremacy over the environment, his pursuit of happiness and his private subjectivity, it contributed in an important way to emancipating him from the logic of status (Sumner Maine 1908) (in which identity was resolved, ascriptively, in the superordinate family, religious and, in a broader sense, "tribal" group) in the name of a contractualisation of his increasingly individualistic identity, of which autonomy was the mainstay. And it is against the background of this normative/descriptive model of autonomy that vulnerability, no longer read as a

\footnotetext{
${ }^{14}$ See also the emergence of the "no-problem problem" identified by Deborah Rhode (1991).
} 
characteristic potential fragility that unites every man in a supportive "social chain", has come to be defined as a special characteristic.

As such, it defines situations that can be labelled as "different", and thus require care and the kind of protection that, having lost the connotations of reciprocity, has come to be configured in the cold, asymmetrical, and basically stigmatising terms of the top-down relationship promoted by performance-based welfare systems.

Against this background, vulnerability has become a comparative characteristic emerging against the backdrop of the normative ideal of autonomy that it logically recalls - aimed at defining some subjects more than others in a given context. These, characteristically, include children, the disabled, the elderly, people in a situation of social and political need or oppression, and people without income - but also (and, in fact, in a special way) women. ${ }^{15}$

It is in this way that the policies of substantive equality supported, in the last decades of the last century, by affirmative actions, as well as the very paradigm of multicultural justice launched in the early 1990s, can be understood. These models of justice, in fact, have been prompted by the criticism, particularly widespread since the 1970s, that universalistic protection inspired by formal equality could not meet the needs of active resistance to the discrimination suffered by disempowered groups (such as women, people of colour, disabled people, or those belonging to stigmatised ethnic groups or sexual orientations) made vulnerable, in this sense, by established social power dynamics. ${ }^{16}$

Within this framework, therefore, the policies designed to support vulnerable identities have found their raison d'être in the need to protect collective identities that are weaker, and can therefore be comparatively labelled as more vulnerable, with respect to the standard effectively defined by Martha Fineman (2004) as "the myth of autonomy".

As various scholars of "care" ethics such as Eva Feder Kittay (1999) and Marian Barnes $(2006,2012)$ have effectively argued, liberalism, starting from the basis provided by the myth of the independence and equal basic autonomy of all, while providing "weaker groups", through classic welfare, with protocols and codified care services, or while bestowing on socially deprived groups, on the basis of policies of substantial equality, special rights and options, has therefore not managed to produce a real "justice for all".

On the contrary: by defining its users as "weak" subjects, "performance-based" welfare, alien to the idea of reciprocity and symmetry, has had the perverse effect of stigmatising them, triggering their further social isolation and producing, in turn, other consequent forms of vulnerability. ${ }^{17}$

\footnotetext{
${ }^{15}$ It is precisely in relation to the status of women, in fact, even before migrants and refugees, that vulnerability (understood as special vulnerability) was first thematised in European law.

${ }^{16}$ In part, this paradigm shift has merged with the results of the new evaluation of difference which, particularly since the 1970s, has led in various areas to a transition from the demand for equal treatment to that for treatment "as equals" respectful of differences (cf. feminism of difference, or movements such as black is beautiful or gay pride), which, since the 1990s, has led to the demand for multicultural policies.

${ }^{17}$ This is well illustrated in the concept of "advanced marginality" (not only with reference to the economy, but also to family and community ties) defined in Loïc Wacquant (2008).
} 


\section{The neo-liberal overreach}

Today, in the era of neo-liberal ethics, this process has gone even further. Identity, conceived essentially as a personal conquest of the "entrepreneur of one's own life", envisages a "liberation" of identity traits geared towards maximum autonomy in the construction of one's self. This is closely correlated with enlargement of the boundaries of one's social group of reference beyond the dimension of the nation state towards a much wider dimension, where even the "other" is abstracted and where the chains linking the various branches of the social whole are declined in terms of an impersonal and top-down bureaucratisation.

But this decline of the great traditional identity structures, this (merely apparent) retreat of the "great inquisitor" and its coercive but reassuring constraints, has actually revealed the extent of the struggle of constructing one's own identity in a free and unencumbered way. In the face of an autonomy that is difficult to manage, this has therefore ended up accentuating the fragility and vulnerability of identity even more.

This autonomy, moreover, finds its counterpart in a maximal responsibilisation of the subject with respect to the management of one's own self: in the logic of selfentrepreneurship, the responsibility of one's destiny and, consequently, of one's own vulnerabilities, is now widely attributed to the vulnerable person himself/herself.

In this way needs and problems previously accommodated within a discourse that converged with the idea of the welfare state are now reinterpreted in neo-liberal terms, within the framework of a project of governmentality that is gradually transforming the idea of care and protection of vulnerable people.

Consistent with this, the current neo-liberal paradigm, even at the criminal level, has by now shifted decisively from commitment to the repression of violence to a focus on the issue of security and, therefore, on the preventive removal of elements of weakness and vulnerability found in society. In line with this, however, even in relation to women's hard-won freedoms, the logic of neo-liberalism is leading towards the naturalisation of a far-from-new model of sexuality regulation which, instead of imposing a duty of respect motivated on the basis of a universal interest in guaranteeing everybody's personal integrity, tends in fact to condone the male predatory instinct. Rather, in many respects, it tends to place the burden of protecting one's own body on women themselves.

The stubborn social and legal resistance to give protection to victims of sexual assaults perpetrated online, for example, is emblematic of this process (Verza 2017). But in such logic, in the first place, there resonates once more precisely that endorsement of the dynamics of aggression awakened by vulnerability - dynamics, after all, here accepted and authorised as "natural" - with respect to which, in a paradoxical return to the ethical "0 level" we started from, the burden of prevention and protection is placed on the person subject to aggression.

Secondly, even in preventive actions aimed at placing under protection the "vulnerable ones" who are incapable of autonomous self-protection, one finds the setback of the protection measure, complete with its relative rigidities and asymmetries. 
Finally, to complete the picture, in the abstract demand for a preventive removal of one's vulnerabilities we find the same "pathogenic" circular process we started from (stigmatising and super-vulnerabilising, incapable of welcoming and tempering human vulnerabilities in a lively and dynamic way and then metabolising them). For all these reasons, in such a political framework, the expression of the special vulnerability of subjects who are "particularly" so, instead of prompting a supportive protection of vulnerability conceived as a common problem, risks bringing very heavy consequences for those who find themselves as really needing protection. It also risks putting responsibility for their weakness on the victims themselves, ultimately accentuating the already present drives to assault their vulnerability or put them under protection.

In the theories of justice that have been proposed throughout the development of Western political ethics, vulnerability has been sometimes framed and protected in its universalist aspect - non-invulnerability and the potential to suffer injuries being perceived as common to all - and sometimes, in other theoretical and practical contexts, in relation to its emergence as a special characteristic of the most vulnerable, and, therefore, not in a universalist but comparative sense. Opting for one or the other of the two ways of understanding vulnerability has obvious consequences on a practical, as well as ethical level: any given translation of sociologically "sensitive" concepts such as this, in fact, consequently pushes towards a certain type of ethical-social horizon.

Both approaches, however, have shown their limitations in the different ways in which they have integrated vulnerability into the liberal ethical-legal-political discourse. On the one hand, if compensation for universalist vulnerability does not succeed in producing substantial equality, on the other more targeted protection of specific vulnerability, if badly managed, ends up exposing the vulnerable to "perverse" compensatory modalities, such as those seen above.

\section{The current rethinking of vulnerability as the foundation of a justice system}

Vulnerability, an elusive, relative and dynamic attribute, is a concept that can be understood in different ways, and none of these can be logically excluded from political discourse - although it is possible (as has historically been done) to give centrality to one rather than the other.

Vulnerability is in fact, as we have seen, first and foremost an ineliminable basic characteristic of each and every person, linked to the limits of man's corporeal and relational nature, which everyone, regardless of gender, race, age, social condition, etc., shares to some extent. It is, therefore, universal. But precisely because this vision, given its very breadth, is so loosely defined that it risks not being able to serve any purpose (Macklin 2003, Levine et al. 2004, Hurst 2008, Luna 2009, Schroeder and Gefenas 2009), it is to its meaning of special vulnerability that the rebalancing mission is entrusted in order to justify more suitable care, aimed at promoting, in a compensatory manner, the ideal of substantial equality. Even this, however, gives rise to contradictions and the potential for more vulnerabilities, generated in the feasible, and conceivably vicious transformations of care itself, which current neo-liberalism is increasingly appropriating.

In neo-liberal philosophy, non-autonomously protected vulnerability is stigmatised and seen as the (guilty) source of the negative reactions it engenders within its environment. 
This is why, in a reaction to this drift, within other theoretical paradigms this very concept is now being called upon to ground the paradigm of justice differently, in positively compensatory terms. From this perspective, authors such as Martha Fineman (with A. Grear, 2013; Fineman 2019), Martha Nussbaum (2001, 2006), ${ }^{18}$ Judith Butler (2004), Catriona Mackenzie (Mackenzie et al. 2014), and others, have identified precisely in human vulnerability the element around which to work in order to overcome the inertia of a tradition that has created its own founding myths by exalting the idea of the autonomy of some at the expense of the political subjectivity of others. The idea is to return to giving centrality, in ways of thinking about social coexistence, to vulnerability understood in its broadest and deepest sense, and to the relational and dependent nature of every human being, as the primary basis of the social pact (on relationality see Nedelsky 1989, 2011, Mackenzie and Stoljar 2000, Harding 2014; to see empirical research on this see also Mäki-Petäjä-Leinonen and Saarelainen 2021). ${ }^{19}$ In the new model that can be extrapolated from a general look at the new theoretical paradigms of vulnerability, the task of re-founding the supporting framework of the current paradigm of justice is entrusted to the interplay between the two meanings, universalistic and special, accompanied by an awareness of the risks of a vicious slide in both directions (towards the endorsement of situations of power and entrenched advantage on the one hand, and super-vulnerabilisation on the other).

Emerging alongside this is the objective of revealing and correcting the deviations deriving from the adoption, in a liberal view, of a definition of the political subject as essentially autonomous, stimulating a new accountability of institutions and civil society in the care of its members. And such a reworking of the idea of vulnerability - abstractly universal and incumbent on all, but in reality experienced currently by some in a "specially" harsh way - is also the element that makes it possible to lay the theoretical foundations of a new and different welfare model, linked by the solidarity principle of subsidiarity to a non-formalistic, but humanly relational perspective of civic participation in the mutual care task (Verza 2014; see Knijn and Lepianka 2020).

This reflection on vulnerability - which, seen in its universal meaning, makes it possible to justify a circulation of care actions on the basis of a circuit of "generalised reciprocity" (à la Polanyi) - overcomes the gap between the State (seen as provider of services) and passive, weak and particularly vulnerable citizens (seen as beneficiaries of these services) by proposing a restructuring of the relationship between citizens and welfare. Moreover, this new relationship would contribute to the creation of a new concept of shared responsibility and "social solidarity" for the care of society as a whole and for its environment. Similarly, Martha Nussbaum's vulnerability approach (2002), centred on recognition of mutual dependence (Bruni 2004) and of the (also intergenerational) symmetry of our needs, and enriched by the conceptual contribution provided by the feminist philosophy of care, has accordingly highlighted the importance of adding to the contractualist and impartial vision of justice the recognition of the importance of the set of activities, relationships, and affects, that precisely constitute the "care" in which compensatory justice is embodied.

\footnotetext{
${ }^{18}$ The idea of vulnerability also underlies the entire structure of Nussbaum's capability approach (2002).

${ }^{19}$ Many thanks to the anonymous reviewer of the journal for the suggestions received on this point.
} 
This would correct, as Annette Baier argued (1994; cf. Raïd 2011), the approach to justice based on an unrealistic vision of freedom of choice and human equality. On the contrary, as Martha Nussbaum (2002) argued, the valorisation of caring actions should be based on the idea of their reciprocity, since the "symmetry of needs" includes, as a human and relational urge, not only the need to receive help but also the need to be in a position to help, thus ratifying one's full membership of, and full contribution to, the social community. It thus goes beyond the marginalising perspective which makes the needy a subject labelled as irreversibly fringe. According to this conception, being needy (and, therefore, intrinsically non-autonomous because always potentially dependent) no longer qualifies as an exception to the rule, but as normality: the elderly, the sick, the young, and women caregivers - themselves vulnerable, given the burden of their caring activities - appear not as permanently vulnerable and "marginal" categories but as embodiments of potentially impending normal phases in the lives of all. They are simultaneoudly always potentially in need of help and also endowed, in turn, with caring capacities and resources that can only be expressed and enhanced in a relational dimension.

Vulnerability, need, and dependence must, therefore, be read not as final, but as contextual and intersecting elements: if, for example, the elderly need someone to do their shopping for them, they could, in turn, prove to be perfect caregivers for sensibly supervising children's play. Many enlightened urban experiences, such as "solidarity apartment blocks" 20 or "time banks", have shown how this resilient and virtuous intersection of needs can not only work, but also restore human warmth to the relationships of mutual care that immeasurably raises their quality (something that an anonymous "service" logic could not do) (Verza 2014).

At the same time, it redefines them from a reciprocal and multi-directional point of view, thus counteracting the risks of a slippage towards the logic of power underlying the dynamics of "caregiving".

As a corollary of the recovery of the value of solidarity and reciprocity arising from the recognition of common vulnerability, even the care provided in the social sphere will therefore have to undergo a conceptual transformation from being considered a right/duty to becoming a "teleological" objective, to be achieved in the common interest of living in a society capable of integrating and accommodating the vulnerability of all. This is especially the case when such vulnerability is unrestrained and erupts into practical and concrete needs, far beyond the abstractness of the language of rights.

\section{Conclusions}

One literary image steeped in symbolism, so charged as to attain the power of myth and to inspire, as a programmatic symbol, an entire artistic movement (the pre-Raphaelites), is that of the Lady of Shalott, celebrated in Alfred Tennyson's famous poem.

Inspired by an ancient legend, the story tells of a woman who lives in a tower on an island along a river leading to Camelot. The Lady of Shalott, because of a prophecy, knows that she can only see Camelot and the rest of the world by filtering it through a

\footnotetext{
20 See, for example, the "intergenerational education" project: http://www.cooperativaunicoop.it/index.php?/abi
} 
mirror placed in front of her window. She thus spends her life isolated and protected from the wounds of the world, observing the distant images of reality reflected in her mirror and experiencing them only virtually, reproducing them in the designs of her tapestry. Her life proceeds in this way until one day, when she sees Lancelot in the mirror, the Lady of Shalott feels "half sick of shadows" and realises that this condition of overprotection is more death than life. So she decides to leave her tower and set off for Camelot even though she knows that her vulnerability, once in contact with the real world from which she has always protected herself, will lead her to death even before the end of the journey.

As this image shows us, the concept of vulnerability is intrinsically complex and, in many ways, even paradoxical. It is precisely those actions aimed at protecting against vulnerability that act hyper-protectively that can end up damaging them, separating subjects (defined as non-normal) from their social world rather than integrating them into it. All too often, in fact, "putting people under protection" ends up, on the one hand, imposing an overly rigid labelling of the vulnerable, and, on the other, substituting a preordained and safe protective strategy for the development of some kind of defence, of "antibodies" ready to spring into action. ${ }^{21}$ This safety, however, is totally unrealistic and circularly dependent on itself. In the end it leads to reproducing, in an accentuated form (in the human body, in psychological systems, in social systems, in ecosystems) the very vulnerability it seeks to escape from.

In the current debate, as we have seen, there are different ways of understanding vulnerability. On the one hand, it is conceived in a minimal sense, as a universal characteristic of everyone which solicits the ethical urgency of favouring a shared system of care that does not treat the needy as deviant. On the other, it is conceived as a characteristic diverging from the standard, which consequently elicits a conscious compensation of the disadvantages serially suffered by the most vulnerable of all. At the same time, we are faced with theories arising from different inspirations: on the one hand, neo-liberal reworkings aimed at minimising the cost for the community of the vulnerabilities of those in a state of need, as if this - forgetting Hobbes's premise - were not a universal condition; on the other, new theories aimed, on the contrary, at focusing on vulnerability itself as the foundation of associated living, thus integrating the universalist reading with the specialist reading of vulnerability. While, in fact, the universalistic dimension defines the equal and symmetrical basis of the common interest in the possibility of care, the other dimension comes into play, in a framework of generalised reciprocity, in concrete cases where the possibility of injury is made a reality. However, as we mentioned above, not even this type of logic can stand on its own unless it is politically and culturally supported - and strongly so - against the unavoidable temptation of abuse and aggression (openly enacted, or indirectly generated by the very protection of the vulnerable).

Only a widespread cultural adherence to these values could be able to support a relevant and lasting change in this direction which could lead to the replacement of individualism, and the "myth of autonomy", with this new ethic of the responsibility of

${ }^{21}$ An interesting social experiment was carried out in Drachten on vulnerability as an effect of the fall of defensive tension. When signs were removed from the most dangerous road junction in the Dutch town, the reactivation of the drivers' sense of alertness led to an increase, rather than a decrease, in safety. 
society, aimed at reinforcing from within, and stemming, vulnerability by organising resources of resistance or resilience, interwoven in the social context. Only in this way could the goal of recovering autonomy return the concept to being framed no longer as an unrealistic descriptive standard, but - as it was in its original dimension - as a normative ideal to be pursued..$^{22}$

Only in this way, finally, in a reciprocal scheme of care based on this conceptual framework, could vulnerability virtuously prompt a resilient protection that is not subtractive, and does not "shalottianly" isolate subjects as "not-in line" according to the "standard" model of autonomy, thus making them, ultimately, even more defenceless against the wounds inflicted by the environment. Only in this way could they be strengthened and positively integrated in their environment through the provision of human and care resources in a social fabric made up, in turn, of people, who are all potentially liable to fall into the same condition.

\section{References}

Bagnoli, C., 2017. Vulnerability and the Incompleteness of Practical Reason. In: C. Straehle, ed., Vulnerability, Autonomy, and Applied Ethics. London: Routledge, 1332.

Baier, A., 1994. The Need for More Than Justice. In: A. Baier, ed., Moral Prejudices: Essays on Ethics. Cambridge, MA: Harvard University Press.

Barnes, M., 2006. Caring and Social Justice. Basingstoke: Palgrave Macmillan.

Barnes, M., 2012. Care in Everyday Life: An Ethic of Care in Practice. Bristol: Policy Press.

Berlin, I., 1991. The Crooked Timber of Humanity. New York: Knopf.

Bruni, L., 2004. L'economia, la felicità e gli altri. Rome: Città Nuova.

Butler, J., 2004. Precarious Life: The Powers of Mourning and Violence. London: Verso.

Butler, J., 2009. Frames of War: When is Life Grievable? London: Verso.

Commons, R., 1934. Institutional Economics. New York: Macmillan.

Deneen, P.J., 2018. Why Liberalism Failed. London: Yale University Press.

Dodds, S., 2014. Dependence, Care, and Vulnerability. In: C. Mackenzie, W. Rogers and S. Dodds, eds., Vulnerability: New Essays in Ethics and Feminist Philosophy. Oxford University Press, 181-203.

Fineman, M., 2004. The Autonomy Myth: A Theory of Dependency. New York: The New Press.

Fineman, M., 2019. Vulnerability and Social Justice. Valparaiso University Law Review [online], 53(2), 341-369. Available from: https://doi.org/10.2139/ssrn.3352825 [Access 1 December 2021].

Fineman, M., and Grear, A., eds., 2013. Vulnerability: Reflections on a New Ethical Foundation for Law and Politics. Farnham: Ashgate. ${ }^{22}$ As Carla Bagnoli (2017) writes, there is no necessary opposition between the aspiration for autonomy and
the inescapability of vulnerability. 
Friedan, B., 1976. La mistica della femminilità. Milan: Edizioni di comunità.

Gibbon, E., 1996. The History of the Decline and Fall of the Roman Empire. London: Penguin.

Goodin, R.E., 1985. Protecting the Vulnerable. Chicago University Press.

Harding, R., 2014. Dementia and Carers: Relationality and Informal Carers' Experiences. In: C. Foster, J. Herring and I. Doron, eds., The Law and Ethics of Dementia. Chicago: Hart, 379-392.

Hart, H.L.A., 1961. The Concept of Law. Oxford University Press.

Hurst, S.A., 2008. Vulnerability in Research and Health Care. Describing the Elephant in the Room? Bioethics, 22(4), 191-202.

Ibn Khaldun, 2005. The Muqaddimah. Princeton University Press.

Kahnemann, D., and Tversky, A., 1979. Prospect Theory: An Analysis of Decision Under Risk. Econometrica, 46(2), 171-85.

Kittay, E.F., 1997. Human Dependency and Rawlsian Equality. In: D.T. Meyers, ed., Feminists Rethink the Self [online]. Boulder: Westview Press, 219-266. Available from: https://doi.org/10.4324/9780429500466-11 [Access 1 December 2021].

Kittay, E.F., 1999. Love's Labor: Essays on Women, Equality and Dependency. New York: Routledge.

Knijn, T., and Lepianka, D., 2020. Justice and Vulnerability in Europe: An Interdisciplinary Approach. Cheltenham: Edward Elgar.

Levine, C., et al., 2004. The Limitation of "Vulnerability" as a Protection for Human Research Participants. American Journal of Bioethics, 4(3), 44-49.

Luna, F., 2009. Elucidating the Concept of Vulnerability: Layers not Labels. International Journal of Feminist Approaches to Bioethics, 2(1), 121-139.

Mackenzie, C., and Stoljar, N., 2000. Relational Autonomy: Feminist Perspectives on Autonomy, Agency and Social Self. Oxford University Press.

Mackenzie, C., Rogers, W., and Dodds, S., eds., 2014. Vulnerability: New Essays in Ethics and Feminist Philosophy. Oxford University Press.

Macklin, R., 2003. Bioethics, Vulnerability and Protection. Bioethics, 17(5-6), 472-486.

Mäki-Petäjä-Leinonen, A., and Saarelainen, S.M., 2021. Funeral Wills and the Autonomy of a Dying Person: Experiences of Older People in Palliative Care and their Carers. International Journal of Law, Policy and the Family [online], 35(1), 1-23. Available from: https://doi.org/10.1093/lawfam/ebab034 [Access 1 December 2021].

Matza, D., 1964. Delinquency and Drift. New York: John Wiley and Sons, Inc.

Natarajan, A.M., Balasubramani, P., and Tamilarasi, A., 2006. Operations Research. Singapore: Pearson Education. 
Nedelsky, J., 1989. Reconceiving Autonomy: Sources, Thoughts, Possibilities. Yale Journal of Law \& Feminism [online], 21/1, 7-36. Available from:

https://digitalcommons.law.yale.edu/yjlf/vol1/iss1/5/ [Access 1 December 2021].

Nedelsky, J., 2011. Law's Relations: A Relational Theory of Self, Autonomy, and Law. Oxford University Press.

Nussbaum, M., 2001. Upheavals of Thought: The Intelligence of Emotions. Cambridge University Press.

Nussbaum, M., 2002. Giustizia sociale e dignità umana: Da individui a persone. Bologna: Il Mulino.

Nussbaum, M., 2006. Frontiers of Justice: Disabilities, Nationalities, Species Membership. Cambridge, MA: Harvard University Press.

Pateman, C., 1988. The Sexual Contract. Redwood City: Stanford University Press.

Raïd, L., 2011. Annette Baier e la critica del liberalismo morale. Iride, 63, 377-92.

Rawls, J., 1972. A Theory of Justice. Oxford University Press.

Rhode, D.L., 1991. The “No Problem” Problem: Feminist Challenges and Cultural Change. Yale Law Journal, 100(6), 1731-1793.

Schroeder, D., and Gefenas, E., 2009. Vulnerability: Too Vague and Too Broad? Cambridge Quarterly of Healthcare Ethics, 18(2), 113-121.

Sumner Maine, H., 1908. Ancient Law. London: Murray.

Tainter, J., 1957. The Meaning of "Political" in Political Decisions. Political Studies [online], 5(3), 225-39. Available from: https://doi.org/10.1111/j.14679248.1957.tb00777.x [Access 1 December 2021].

Tainter, J., 1988. The Collapse of Complex Societies. Cambridge University Press.

Toynbee, A.J., 1988. A Study of History. Oxford University Press.

Turner, B.S., 2021. Vulnerability and Human Rights. University Park: Pennsylvania State University Press.

Verza, A., 2014. Principio di sussidiarietà e universalità dei bisogni: il riaccendersi tecnologico della fiducia. Notizie di Politeia, 116, 14-35.

Verza, A., 2016. La sicurezza nel contesto domestico: un'introduzione sociologica. In: F. Curi, ed., Ordine pubblico e sicurezza nel governo della città. Bologna: BUP, 241-250.

Verza, A., 2017. Aggredire attraverso l'immagine. Cristallizzazioni tecnologiche, genere e diniego di tutela nella logica disciplinante neoliberale. Ragion Pratica, 2, 467-492.

Wacquant, L., 2008. Urban Outcasts. Cambridge: Polity Press.

Zanetti, G., 2019. Filosofia della vulnerabilità: Percezione, discriminazione, diritto. Rome: Carocci. 